\title{
Erratum \\ Noradrenergic $\alpha$ l Receptors as a Novel Target for the Treatment of Nicotine Addiction
}

Benoit Forget, Carrie Wertheim, Paola Mascia, Abhiram Pushparaj, Steven R. Goldberg and Bernard Le Foll

Neuropsychopharmacology (2010) 35, 2006; doi:10.1038/npp.2010.62

Correction to: Neuropsychopharmacology advance online publication, 31 March 2010; doi:10.1038/npp.2010.42
In this article, the data below Table 2 are incorrect. Table 2 is republished here with the correct data.

Table 2 Response Rates of Rats During the Drug Discrimination Study at Different Nicotine Doses (0-0.4 mg/kg) After Prazosin $(0-1 \mathrm{mg} / \mathrm{kg})$ Pretreatment

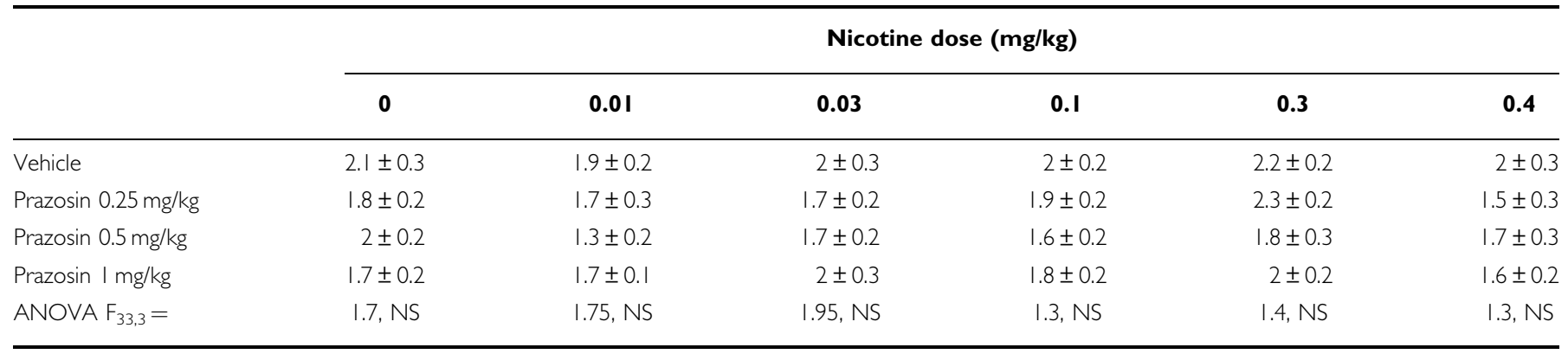

Data are expressed as rate of responding on levers (in lever presses/sec \pm SEM). 